Abstracted/indexed in Academic Search Complete, Asia Journals Online, Bangladesh Journals Online, Biological Abstracts, BIOSIS Previews, CAB Abstracts, Current Abstracts, Directory of Open Access Journals, EMBASE/Excerpta Medica, Google Scholar, HINARI (WHO), International Pharmaceutical Abstracts, Open J-gate, Science Citation Index Expanded, SCOPUS and Social Sciences Citation Index

ISSN: $1991-0088$

\title{
Speciation of arsenic in vegetables and their correlation with inorganic phosphate level
}

\author{
Jahanara Laizu
}

Department of Pharmacology, Bangabnadhu Sheikh Mujib Medical University, Dhaka, Bangladesh.

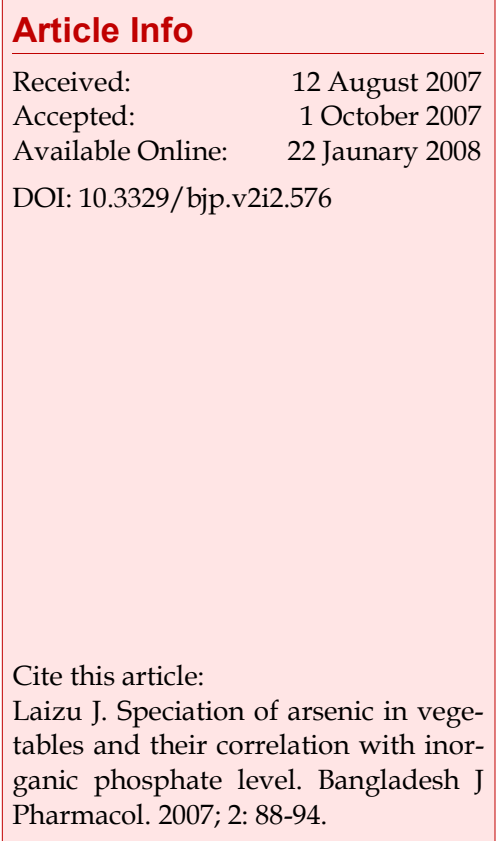

Accepted:

1 October 2007

\begin{abstract}
A total 400 vegetable sample of 20 varieties of three categories were collected from a local market of Dhaka city. Speciation of arsenic (inorganic arsenic, MMA and DMM) and the amount of inorganic phosphate were estimated. There was no significant variation in the concentrations of inorganic phosphate levels amoung the three categories of vegetables. But in case of arsenic accumulation the fruiting vegetables, root and tuber vegetables and leafy vegetables showed significant variation. There was either positive or negative relationship present in inorganic phosphate and speciated arsenic among the vegetables. Significant negative relationship between inorganic phosphate and inorganic arsenic is observed in different types of fruiting vegetables e.g., bitter ground, tomato; between inorganic phosphate and DMA in bitter gourd; and between inorganic phosphate and total arsenic in bitter gourd, lady's finger, and tomato. The fruiting vegetables contained low level of arsenic, which might have some relationship with higher level of inorganic phosphate. In root and tuber vegetables, significant relationship was present in arum. But in case of arum loti significant positive relationship was observed between inorganic phosphate and DMA. The present study shows that the leafy vegetables contained higher level of inorganic phosphate in contrast to arsenic, though they had no significant relationship between inorganic phosphate and different speciated form of arsenic.
\end{abstract}

\section{Introduction}

Arsenic is a highly toxic element and its presence in food composites is a matter of concern to the wellbeing of both humans and animals. Recent reports have shown that some of our foodstuffs are also contaminated with arsenic (Huq et al., 2003; Meharg and Rahman, 2003; Das et al., 2004). It might be due to the high concentrations of arsenic in the soil where the foodstuffs are grown.

In most foodstuffs, arsenic mainly occurs in the organic forms and concentration usually less than $1 \mathrm{mg} / \mathrm{kg}$ (Khan and Ahmed, 1997). Arsenic in the environment will be leached into the soil, absorbed by plants and further entering the food chain and affecting food safety. In Bangladesh, the people are not only drinking ground water but also using this water for cooking, household works and irrigation. Bangladesh is primarily based on agriculture. However, widespread uses of ground water for irrigation suggested that ingestion of irrigated crops and vegetables could be another major exposure route for arsenic (WHO, 2001; Duxbury et al., 
2004). The vegetables are important food crops of Bangladesh and are rich in vitamins and minerals, which are very essential for maintaining good health. Most of the vegetables contain more than 80 percent water. Dietary plants also contain hundreds of antioxidants.

Fitz and Wenzel, (2002) stated that the speciation of arsenic in environmental materials was of interest because of the differing levels of toxicity exhibited in the environment by the various species. The major arsenic species found in environment were arsenite, arsenate, arsenious acid, arsenic acid, monomethylarsenic acid (MMA), dimethylarsenic acid (DMA), arsenobetaine $(\mathrm{AB})$ and arsenocholine $(\mathrm{AC})$.

Inorganic arsenic is the predominant form in the soil and is toxic to the plant. Methylated form of MMA and DMA is also present due to photooxidation and microbial biotransformation in the soil.

High arsenic irrigated water and soil appears to result in higher concentration of arsenic in root, stem and leaf of rice plants (Abedin et al., 2002). Meharg et al. (2003) observed that both As (III) and MMA are phytotoxic to rice plants grown on nutrient solutions and the degree of arsenic uptake by rice followed as As (III) $>$ MMA $>$ As (V)>DMA. A number of studies have shown that there was reduced growth of plants when grown in soil containing high arsenic or when irrigated with water containing high concentration of arsenic (Abedin et al., 2002).

Arsenic is a non-essential element but phosphate is an essential element for the plant. Arsenic exists in environment in the form of organic and inorganic (WHO, 2001) of which inorganic is more acutely toxic. Inorganic arsenic further exists in environment in the forms e.g As (III), (AsV). Phosphate is the $3^{\text {rd }}$ most nutrient element for the plant; it is also necessary for energy transfer, photosynthesis, root development and flowering. Inorganic phosphate resembles pentavalent arsenic. Uptake of pentavalent arsenic is inhibited by the phosphate because they compete for the same sorption site and share the same physiochemical properties. Therefore, the need for determination of arsenic concentration in vegetables of Bangladesh was given serious consideration (Huq and Naidu, 2003; Das et al., 2004).

The vegetables are important food crops of Bangladesh. But vegetables that are grown in arsenic contaminated soil, people unknowingly consume such arsenic contaminated crops and become exposed to arsenic toxicity. To prevent the toxicity several measures or techniques are suggested to minimize arsenic mobility in the soil and uptake by the plants. There are many competing ions, which may alleviate or reduce the arsenic accumulation by the plants. Phosphate is one of such competing ions, which is used as a fertilizer in irrigated field, which may compete with arsenic for sorption site and accumulate in vegetable for nutrition purpose. The unknowing ingestion of a toxic substance like arsenic may be hazardous to human health. Long time exposure of low doses of arsenic causes chronic toxicity.

In the above circumstances, the study was undertaken to see the concentration of arsenic and inorganic phosphate which are present in different vegetables and the relationship among the inorganic arsenic, MMA and DMA with the inorganic phosphate.

\section{Materials and Methods}

\section{Chemicals}

The following chemicals were used: Arsenic trioxide (Sigma Aldrich, USA), lead acetate (Loba Chemie, India) potassium iodide solution (BDH Chemicals, UK) stannous chloride (Loba Chemie, India), silver diethyldithiocarbamate (E. Merck, Germany), hexamethylenetetramine (E. Merck, Germany)

\section{Vegetables}

In total 400 vegetable samples of 20 varieties of three categories were collected from a local market of Dhaka city. These were a) fruiting vegetables: Bean, bittergourd, brinjal, cauliflower, frenchbean, lady's finger, green papaya, parble, pumpkin and tomato, b) root and tuber vegetables: Arum, arum loti, carrot, potato, radish, and c) leafy vegetables: Datashak kolmishak, lalshak, Indian spinach and spinach. Twenty samples of each variety weighing range from 200-250 g were purchased. Each vegetable was washed with water and dried. The vegetables were packed with polythene bag and appropriately labeled. Then packed vegetables were kept in $-20^{\circ} \mathrm{C}$ until analysis for arsenic speciation and phosphate level.

\section{Speciation determination of arsenic in common vegetables}

At first vegetables were measured then chopped into small pieces and dissolved in $5 \mathrm{~mL}$ of $50 \%$ methanol in a container for 12 hours (D' Amato et al., 2004). It was filtered and the filtrate poured into the cation-exchange column chromatography for the separation of arsenic performed according to the method of Tam et al. (1978) on columns of AG $50 \mathrm{WX}-8$ resin by which inorganic arsenic, MMA, DMA were subsequently eluted with 15 $\mathrm{mL}$ of $0.5 \mathrm{M} \mathrm{HCI}, 15 \mathrm{~mL}$ of deionized water and $30 \mathrm{~mL}$ 
of $4 \mathrm{~N} \mathrm{NH}_{4} \mathrm{OH}$ solution. Then the different arsenic concentrations were determined by SDDC method.

\section{Estimation of arsenic concentration in samples (by SDDC method)}

For the estimation of arsenic three arsine generator flask, (one for inorganic arsenic, one for MMA, one for DMA) were taken in which $15 \mathrm{~mL}$ sample and $15 \mathrm{~mL}$ deionized water was taken. Five $\mathrm{ml}$ of concentrated hydrochloric acid and $50 \mathrm{~mL}$ of potassium iodide solution were added to the flask. The flask was whirled gently to mix and allowed to stand for one min. Then few drops of stannous chloride solution (approximately $0.5 \mathrm{~mL}$ ) were added until the solutions became colorless. Proportionate amount of cotton wool, moistened with a few drops of $10 \%$ lead acetate solution was placed tightly into the proximal absorber part and attached with the generator. Three milliliters of SDDC reagents were taken through the open-end test tube of the distal absorber part. Three grams of granular zinc pellet was added to the generator flask and double bend absorber part was connected immediately to ensure that no gas could escape from the system. After few min the reaction took place showing bubbles within the generator flask and the bubbles passed through the yellow color SDDC reagents, the reaction was allowed to continue until the bubbling stop (approximately 30 $\mathrm{min}$ ). After $30 \mathrm{~min}$, the coloring reagent (SDDC solution) was transferred into a test tube and filled to the mark with chloroform. Finally absorbances were measured at $525 \mathrm{~nm}$.

\section{Estimation of phosphate concentration in samples (George et al., 1942)}

The vegetables were allowed to attain room temperature prior to use. At first sample was measured. Hundred grams of each vegetable was taken in a hand homogenizer and homogenated in presence of $7.5 \mathrm{~mL}$ TCA $(10 \%)$ at room temperature. The homogenate was then centrifuged at $1,725 \mathrm{x}$ for $5 \mathrm{~min}$. The supernatant was carefully transferred to another appropriately labeled test tube and preserved at room temperature until estimation of phosphate was done. The working reagents of ammonium molybdate $(1 \mathrm{~mL})$ and metol $(1$ $\mathrm{mL}$ ) were added to the test tubes. Then the contents of the test tubes were mixed by vortex and incubated at room temperature for $30 \mathrm{~min}$. After $30 \mathrm{~min}$ coloring reagent was transferred to a glass cuvettee and absorbance was read at $680 \mathrm{~nm}$ in a spectrophotometer. The concentration of the phosphate was calculated from the standard curve. Alternatively the concentration of phosphate was calculated from the following formula.

\section{Data collection and statistical analysis}

All the results were recorded in the computer in tabulated form. Statistical analyses were carried out using Statistical Package for Social Science (SPSS), version 10, USA. Pearson correlation-coefficient was done to see the relation between inorganic phosphate and arsenic (inorganic arsenic, MMA, DMA and total arsenic). $\mathrm{p}$ value less than $0.05,0.001$ was taken for statistical significance.

\section{Results}

Table I shows the higher accumulation of total arsenic (mean $\pm \mathrm{SD})$ was found in parble $(3.2 \pm 2.9 \mu \mathrm{g} / \mathrm{g})$, papaya $(2.4 \pm 2.3 \mu \mathrm{g} / \mathrm{g})$, bean $(2.2 \pm 1.9 \mu \mathrm{g} / \mathrm{g})$, arum (3.9 $\pm 1.7 \mu \mathrm{g} / \mathrm{g})$, arum loti $(3.0 \pm 2.9 \mu \mathrm{g} / \mathrm{g})$ and carrot $(2.4 \pm$ $2.4 \mu \mathrm{g} / \mathrm{g})$. Comparatively lower accumulation was found in kolmishak $(0.5 \pm 0.2 \mu \mathrm{g} / \mathrm{g})$ and lalshak $(0.8 \pm$ $0.8 \mu \mathrm{g} / \mathrm{g})$. Among the total arsenic in foodstuffs, the amount of inorganic arsenic is more important. Our study shows that higher accumulation of inorganic arsenic among the fruiting vegetables was found in parble $(1.3 \pm 1.2 \mathrm{mg} / \mathrm{g})$, arum lati $(1.1 \pm 1.1 \mathrm{mg} / \mathrm{g})$, arum $(1.5 \pm 0.9 \mathrm{mg} / \mathrm{g})$ among the root and tuber vegetables. Lower accumulation was found in kolmishak $(0.2 \pm 0.1 \mu \mathrm{g} / \mathrm{g})$ and lalshak $(0.5 \pm 0.3 \mu \mathrm{g} / \mathrm{g})$, in leafy vegetables.

MMA was found in relatively higher amount in parble $(1.1 \pm 0.9 \mu \mathrm{g} / \mathrm{g})$, lower accumulation was found in lalshak $(0.2 \pm 0.4 \mu \mathrm{g} / \mathrm{g})$ and kolmishak $(0.1 \pm 0.1 \mu \mathrm{g} / \mathrm{g})$. Higher accumulation of DMA was found in parble $(0.9$ $\pm 1.1 \mu \mathrm{g} / \mathrm{g})$, papaya $(1.1 \pm 1.0 \mu \mathrm{g} / \mathrm{g})$ arum $(1.6 \pm 1.0 \mu \mathrm{g} /$ g) and arum loti $(1.0 \pm 1.2 \mu \mathrm{g} / \mathrm{g})$. However, lower accumulation was found in tomato $(0.3 \pm 0.2 \mu \mathrm{g} / \mathrm{g})$, kolmishak $(0.2 \pm 0.1 \mu \mathrm{g} / \mathrm{g})$ and lalshak $(0.1 \pm 0.1 \mu \mathrm{g} / \mathrm{g})$.

The higher accumulation of inorganic phosphate was present in brinjal $(2.0 \pm 1.2 \mathrm{mg} / \mathrm{g})$, bitter gourd $(2.2 \pm 1.2$ $\mathrm{mg} / \mathrm{g})$ and lower accumulation was present in arum $(0.7-2.9 \mathrm{mg} / \mathrm{g})$, carrot $(0.7-2.9 \mathrm{mg} / \mathrm{g})$, lalshak (1.2-4.5 $\mathrm{mg} / \mathrm{g}$ ) and kolmishak (0.5-5.8 $\mathrm{mg} / \mathrm{g})$. The lower accumulation of inorganic phosphate was present in cauliflower $(0.6 \pm 0.4 \mathrm{mg} / \mathrm{g})$, tomato $(0.4 \pm 0.1 \mathrm{mg} / \mathrm{g})$ and $(0.1-0.5 \mathrm{mg} / \mathrm{g})$ in fruiting vegetables and puishak $(0.4 \pm 0.2 \mathrm{mg} / \mathrm{g})$ and spinach $(0.3 \pm 0.1 \mathrm{mg} / \mathrm{g})$ in leafy vegetables.

Table II shows the quartile values of inorganic phosphate and total arsenic. The relationship present between arsenic and phosphate in different types of vegetable which may be either positive or negative. When the concentration of inorganic phosphate was increased, the arsenic concentration was gradually decreased. The significant negative relationship was 


\begin{tabular}{|c|c|c|c|c|c|c|c|c|c|c|}
\hline \multicolumn{11}{|c|}{ Table I } \\
\hline \multicolumn{11}{|c|}{ Concentration of total arsenic in different types of vegetables $(n=20$, each) } \\
\hline & $\begin{array}{c}\text { Total } \\
\text { arsenic }\end{array}$ & $\begin{array}{c}\text { Total } \\
\text { arsenic }\end{array}$ & $\begin{array}{l}\text { Inor- } \\
\text { ganic } \\
\text { arsenic }\end{array}$ & $\begin{array}{l}\text { Inor- } \\
\text { ganic } \\
\text { arsenic }\end{array}$ & MMA & MMA & DMA & DMA & $\begin{array}{l}\text { Inor- } \\
\text { ganic } \\
\text { phos- } \\
\text { phate }\end{array}$ & $\begin{array}{l}\text { Inor- } \\
\text { ganic } \\
\text { phos- } \\
\text { phate }\end{array}$ \\
\hline $\begin{array}{l}\text { Fruiting } \\
\text { vegetables }\end{array}$ & Range & $\begin{array}{l}\text { Mean } \pm \\
\text { SD }\end{array}$ & Range & $\begin{array}{c}\text { Mean } \pm \\
\text { SD }\end{array}$ & Range & $\begin{array}{l}\text { Mean } \pm \\
\text { SD }\end{array}$ & Range & $\begin{array}{c}\text { Mean } \pm \\
\text { SD }\end{array}$ & Range & $\begin{array}{c}\text { Mean } \pm \\
\text { SD }\end{array}$ \\
\hline Parble & $0.0-8.3$ & $3.2 \pm 2.9$ & $0.0-3.2$ & $1.3 \pm 1.2$ & $0.0-2.8$ & $1.1 \pm 0.9$ & $0.0-3.2$ & $0.9 \pm 1.1$ & $0.3-2.1$ & $0.9 \pm 0.4$ \\
\hline Papaya & $0.0-7.2$ & $2.4 \pm 2.3$ & $0.0-1.5$ & $0.5 \pm 0.5$ & $0.0-3.1$ & $0.8 \pm 0.9$ & $0.0-2.8$ & $1.1 \pm 1.0$ & $0.0-2.3$ & $1.0 \pm 0.5$ \\
\hline Bean & $0.0-7.4$ & $2.2 \pm 1.9$ & $0.0-2.2$ & $0.6 \pm 0.6$ & $0.0-4.6$ & $0.7 \pm 1.1$ & $0.0-2.2$ & $0.8 \pm 0.7$ & $0.2-1.3$ & $0.7 \pm 0.3$ \\
\hline French bean & $0.3-3.7$ & $2.1 \pm 1.0$ & $0.0-2.1$ & $0.8 \pm 0.6$ & $0.0-0.8$ & $0.5 \pm 0.3$ & $0.0-1.6$ & $0.8 \pm 0.5$ & $0.8-2.7$ & $1.4 \pm 0.6$ \\
\hline Brinjal & $0.0-7.2$ & $1.7 \pm 2.0$ & $0.0-3.0$ & $0.8 \pm 1.0$ & $0.0-1.9$ & $0.3 \pm 0.4$ & $0.0-4.4$ & $0.7 \pm 1.1$ & $0.9-5.7$ & $2.0 \pm 1.2$ \\
\hline Bitter gourd & $0.0-9.8$ & $1.5 \pm 2.2$ & $0.0-2.5$ & $0.4 \pm 0.6$ & $0.0-3.9$ & $0.5 \pm 0.7$ & $0.0-3.4$ & $0.5 \pm 0.8$ & $0.8-4.6$ & $2.2 \pm 1.2$ \\
\hline $\begin{array}{l}\text { Lady's fin- } \\
\text { ger }\end{array}$ & $0.1-4.9$ & $1.4 \pm 1.2$ & $0.0-2.1$ & $0.7 \pm 0.6$ & $0.0-1.0$ & $0.3 \pm 0.4$ & $0.0-3.5$ & $0.4 \pm 0.8$ & $0.3-3.3$ & $1.4 \pm 0.9$ \\
\hline Pumpkin & $0.0-7.3$ & $1.4 \pm 1.5$ & $0.0-2.2$ & $0.7 \pm 0.6$ & $0.0-2.9$ & $0.3 \pm 0.7$ & $0.0-2.3$ & $0.3 \pm 0.6$ & $0.8-2.1$ & $1.4 \pm 0.5$ \\
\hline Cauliflower & $0.1-3.6$ & $0.8 \pm 0.8$ & $0.0-1.4$ & $0.4 \pm 0.5$ & $0.0-0.6$ & $0.2 \pm 0.2$ & $0.0-1.6$ & $0.2 \pm 0.3$ & $0.3-2.0$ & $0.6 \pm 0.4$ \\
\hline Tomato & $0.1-1.5$ & $0.7 \pm 0.5$ & $0.0-1.0$ & $0.3 \pm 0.3$ & $0.0-0.4$ & $0.1 \pm 0.1$ & $0.0-0.5$ & $0.3 \pm 0.2$ & $0.0-0.6$ & $0.4 \pm 0.1$ \\
\hline \multicolumn{11}{|l|}{$\begin{array}{l}\text { Root and } \\
\text { tuber vege- } \\
\text { tables }\end{array}$} \\
\hline Arum & $1.0-7.7$ & $3.9 \pm 1.7$ & $0.0-3.4$ & $1.5 \pm 0.9$ & $0.1-2.3$ & $0.8 \pm 0.7$ & $0.0-2.9$ & $1.6 \pm 1.0$ & $0.7-2.9$ & $1.8 \pm 0.7$ \\
\hline Arum loti & $0.4-11.0$ & $3.0 \pm 2.9$ & $0.0-3.7$ & $1.1 \pm 1.1$ & $0.0-3.6$ & $1.0 \pm 1.1$ & $0.0-4.1$ & $1.0 \pm 1.2$ & $0.3-2.2$ & $1.2 \pm 0.7$ \\
\hline Carrot & $0.1-8.4$ & $2.4 \pm 2.4$ & $0.0-4.8$ & $0.9 \pm 1.0$ & $0.0-3.1$ & $0.7 \pm 0.9$ & $0.0-2.8$ & $0.7 \pm 0.9$ & $0.7-2.9$ & $1.6 \pm 0.6$ \\
\hline Radish & $0.1-4.6$ & $2.0 \pm 1.3$ & $0.0-1.5$ & $0.7 \pm 0.5$ & $0.0-2.1$ & $0.5 \pm 0.6$ & $0.0-2.7$ & $0.7 \pm 0.7$ & $0.5-2.5$ & $1.4 \pm 0.5$ \\
\hline Potato & $0.3-7.1$ & $1.9 \pm 2.1$ & $0.0-2.6$ & $0.7 \pm 0.8$ & $0.0-3.8$ & $0.6 \pm 0.9$ & $0.0-3.9$ & $0.6 \pm 1.0$ & $0.4-1.7$ & $0.9 \pm 0.4$ \\
\hline \multicolumn{11}{|l|}{$\begin{array}{l}\text { Leafy vege- } \\
\text { tables }\end{array}$} \\
\hline Puishak & $0.2-4.3$ & $1.5 \pm 1.0$ & $0.0-3.2$ & $0.7 \pm 0.7$ & $0.0-1.1$ & $0.6 \pm 0.3$ & $0.0-2.3$ & $0.3 \pm 0.5$ & $0.2-0.9$ & $0.4 \pm 0.2$ \\
\hline Spinach & $0.2-3.8$ & $1.1 \pm 1.0$ & $0.0-1.3$ & $0.3 \pm 0.4$ & $0.0-2.7$ & $0.5 \pm 0.8$ & $0.0-1.3$ & $0.3 \pm 0.3$ & $0.1-0.5$ & $0.3 \pm 0.1$ \\
\hline Datashak & $0.0-3.7$ & $1.1 \pm 1.1$ & $0.0-1.2$ & $0.3 \pm 0.3$ & $0.0-1.9$ & $0.4 \pm 0.6$ & $0.0-1.3$ & $0.3 \pm 0.4$ & $0.4-2.6$ & $1.5 \pm 0.5$ \\
\hline Lalshak & $0.0-2.8$ & $0.8 \pm 0.8$ & $0.0-0.9$ & $0.5 \pm 0.3$ & $0.0-1.5$ & $0.2 \pm 0.4$ & $0.0-0.6$ & $0.1 \pm 0.1$ & $1.2-4.5$ & $2.7 \pm 0.9$ \\
\hline Kolmishak & $0.0-0.8$ & $0.5 \pm 0.2$ & $0.0-0.5$ & $0.2 \pm 0.1$ & $0.0-0.2$ & $0.1 \pm 0.1$ & $0.0-0.4$ & $0.2 \pm 0.1$ & $0.5-5.8$ & $1.7 \pm 1.4$ \\
\hline
\end{tabular}

observed in tomato $(\mathrm{r}=-0.473, \mathrm{p}<0.05)$, lady's finger $(r=-0.495, p<0.05)$, and bitter ground $(r=-0.452$, $\mathrm{p}<0.05)$.

The significant negative relationship between inorganic phosphate and inorganic arsenic was observed in arum $(r=-0.488, p<0.05$; data not shown). In addition there was relationship present between inorganic phosphate and the MMA but was not statistically significant.

The negative relationship was observed between inorganic phosphate and DMA. But the significant negative relationship was present between inorganic phosphate and DMA in bitter gourd $(r=-0.448, p<0.05)$. In root and tuber vegetables there was positive relationship with arum loti which was statistically significant $(\mathrm{r}=+0.537, \mathrm{p}<0.05)$ (data not shown).

\section{Discussion}

Among the studied vegetables some vegetables contained more arsenic. In the present study higher accumulation of total arsenic in root and tuber vegetables in which the edible portion below the ground was found in arum, arum loti and carrot. In comparison to other types of vegetable, root and tuber vegetables contained inorganic arsenic, MMA and DMA. However these levels were lower than those found in vegetable (root of potato up to $2.9 \mathrm{mg} / \mathrm{kg}$ ) reported by Abedin et al. (2002). Also these levels were lower than those found in rice roots e.g. $1.8 \mathrm{mg} / \mathrm{kg}$ reported by Meharg et al. (2003). Abedin et al. (2002) revealed in speciation of arsenic in rice straw, that the predominant species present in rice straw was pentavalent arsenic followed 


\begin{tabular}{|c|c|c|c|c|}
\hline \multicolumn{5}{|c|}{ Table II } \\
\hline \multicolumn{5}{|c|}{ Relation between the concentration of inorganic phosphate and total arsenic in different quartile } \\
\hline Vegetable & $\begin{array}{c}\text { Inorganic phosphate } \\
(\mathrm{mg} / \mathrm{g}) \text { mean } \pm \mathrm{SD}\end{array}$ & $\begin{array}{c}\text { Total arsenic } \\
(\mathrm{mg} / \mathrm{g}) \text { mean } \pm \mathrm{SD}\end{array}$ & r value & $\mathrm{p}$ value \\
\hline Tomato & & & -0.473 & $<0.05$ \\
\hline 1st quartile & $0.3 \pm 0.1$ & $0.9 \pm 0.6$ & & \\
\hline 2nd quartile & $0.4 \pm 0.03$ & $0.8 \pm 0.5$ & & \\
\hline 3rd quartile & $0.5 \pm 0.05$ & $0.6 \pm 0.4$ & & \\
\hline 4th quartile & $0.6 \pm 0.03$ & $0.5 \pm 0.3$ & & \\
\hline Lady's finger & & & -0.495 & $<0.05$ \\
\hline 1st quartile & $0.5 \pm 0.1$ & $2.3 \pm 1.7$ & & \\
\hline 2nd quartile & $0.9 \pm 0.4$ & $1.6 \pm 0.9$ & & \\
\hline 3rd quartile & $1.8 \pm 0.7$ & $1.2 \pm 1.0$ & & \\
\hline 4th quartile & $2.4 \pm 0.5$ & $0.6 \pm 0.6$ & & \\
\hline Bitter gourd & & & -0.452 & $<0.05$ \\
\hline 1st quartile & $0.8 \pm 0.1$ & $3.4 \pm 3.9$ & & \\
\hline 2nd quartile & $1.7 \pm 0.4$ & $1.3 \pm 0.4$ & & \\
\hline 3rd quartile & $2.3 \pm 0.5$ & $0.8 \pm 0.6$ & & \\
\hline 4th quartile & $3.9 \pm 0.7$ & $0.7 \pm 0.6$ & & \\
\hline
\end{tabular}

by trivalent arsenic and DMA in vegetable sample performed due to arsenic transportation to the vegetable.

Leafy vegetables, which are easily available, and readily consumed by the people of Bangladesh especially in rural area. In present study, inorganic arsenic, MMA and DMA concentration varied in different types of leafy vegetables e.g. kolmishak and lalshak, datashak, puishak. Mitra et al. (2004) determined the level of arsenic content of crop, vegetables in different regions of Bangladesh and found there were differences e.g., kachu shak, potatoes and kalmi shak. However these levels were higher than the present study. A study conducted by Huq et al. (2003) showed that arsenic concentrations in the soil of different districts of Bangladesh were less than $10 \mathrm{mg} / \mathrm{kg}$. The surface (0-15 $\mathrm{cm})$ soil contains more arsenic than the subsurface (16$30 \mathrm{~cm})$ soil. It may be due to arsenic contaminated water that is carried out every year by flood (Cornu et al., 2003; Malimai-Raja et al., 2005; Williams et al., 2003).

Higher level of concentrations of inorganic arsenic parble are found in arum lati and arum. Higher accumulation of MMA was found in parble in fruiting vegetables. In the present study, parble contained the higher level of inorganic arsenic, MMA and DMA. Meharg et al. (2002) reported that accumulation of arsenic varies from place to place and crop to crop, the reason may be due to variation in soil properties and variation in crop physiology and morphology. In this study, the amount of inorganic arsenic was more than the organic one which may be due to metabolism.

Higher accumulation of DMA was found in papaya, arum and arum loti, and lower accumulation was found in kolmishak and lalshak respectively, in fruiting vegetables, root and tuber vegetables and leafy vegetables.

Abedin et al. (2002) reported that the uptake rate in rice at $0.05 \mathrm{mM}$ of arsenate decreased significantly $(\mathrm{p}<0.001)$ with increasing phosphate concentration present in the incubating solution.

Arsenic is a chemical analogue of pentavalent arsenic. Phosphate may complete with arsenic for plant uptake (Cao et al., 2003). On the other hand, phosphate addition as a fertilizer, which is essential for plant development to arsenic contaminated soils, would enhance arsenic release from soil through competitive exchange (Smith et al., 2002). To alleviate arsenic toxicity, plants must take up sufficient amount of phosphate to balance excessive arsenic (Carbonell-Barrachina et al., 1998).

The present study also shows that, the higher accumulation of inorganic phosphate hate was present in brinjal, bitter gourd, lady's finger, arum, carrot, lalshak and kolmishak.

Relationship between arsenic and phosphate in different type of vegetables were present which may be either positive or negative. Cao et al., (2003) observed that great part of the phosphates in soil is adsorbed into soil particles or incorporated into soil organic matter, 
and accumulation through the plant has much greater affinity for phosphate uptake than arsenic. In case of fruiting vegetables, significant negative relationship between inorganic phosphate and inorganic arsenic is observed in bitter ground tomato, between inorganic phosphate and DMA in bitter gourd; and between inorganic phosphate and total arsenic in bitter gourd, lady's finger, and tomato, and arum. On the other hand other vegetables had either negative or positive relationship but not significant.

In addition to root and tuber vegetables, there was significant positive relationship observed between inorganic phosphate and DMA in arum loti. Tu and Ma (2003) have been reported that there was a positive correlation between plant phosphate and arsenic concentration in brake fern. Holtan et al. (2004) reported that the solubility of phosphates is controlled by either sorption-desorption or precipitation dissolution reactions depending on the environment in the soil or sediments.

In case of leafy vegetables, there was no significant relationship among inorganic phosphate and arsenic (inorganic arsenic, MMA and DMA).

In the present study, either a positive or negative relationship have found between inorganic phosphate and speciated form of arsenic among the vegetables. Among the three categories of vegetables, leafy vegetables which are easily available and consumed by the people of Bangladesh almost certainly contain higher range of inorganic phosphate. Contrary, leafy vegetables accumulate lower range of arsenic which is beneficial for the human health. Some fruiting vegetables, e.g., bitter gourd, tomato, lady's finger comparatively accumulated higher range of inorganic phosphate.

\section{Acknowledgement}

I am grateful to Prof. Mir Misbahuddin of Bangabandhu Sheikh Mujib Medical University, Dhaka, for his kind support and encouragement throughout this work.

\section{References}

Abedin MJ, Feldmann J, Meharg AA. Uptake kinetics of arsenic species in rice plants. Plant Physiol. 2002; 128: 112028.

Carbonell-Barrachina AA, Arabi MA, Delaune RD, Gambrell $\mathrm{RP}$, Patrick, JWH. Arsenic is wetland vegetation, availability phytotoxicity uptake and effects on plant growth and nutrition. Sci Total Environ. 1998; 217: 189-99.

Cao X, Ma LQ, Shiralipour A. Effect of compost and phosphate amendments on arsenic mobility in soils and arsenic uptake by the hyperaccumulator Pteris vittata L. Environ Pollute. 2003; 126: 157-67.

Chakraborti D, Rahman MM, Paul K, Chowdhury UK, Chanda CR, Lodh D, Saha K C, Mukherjee S, Roy S, Das R, Palit K, Kaises I, Barua AK, Rahman M, Quamruzzaman Q. Groundwater arsenic contamination in south East Asia, with special reference to Bangladesh and West Bengal, India. Arsenic in the Asia-Pacific region workshop. 2001; 20-23. Adelaide, SA, pp 1-4.

Duxbury JM, Mayer AB, Laure JG, Hassan N. Food chain aspects of arsenic contamination in Bangladesh: Effects on quality ands productivity of rice. J Environ Sci Health A Tox Hazard subst Environ Eng. 2003; 38: 61-69.

D' Amato M, Forte G, Caroli S. Identification and quantification of major species of arsenic in rice. JAOAC Int. 2004; 87: 238-43.

Das HK, Mitra AK, Sengupta PK, Hossain A, Islam F, Rabbani $\mathrm{GH}$. Arsenic concentrations in rice, vegetables, and fish in Bangladesh: A preliminary study. Environ Int. 2004; 30: 383 87.

Fitz WJ, Wenzel WW. Arsenic transformations in the soilrhizosphere-plant system, fundamentals and potential application to phytoremediation. J Biotechnol. 2002; 99: 25978.

George YS, Cois MJ, Harry LR. The estimation of serum inorganic phosphate and acid and alkaline phosphate activity. J Biochem. 1942; 142: 921-33.

Huq SMI, Naidu R. Arsenic in groundwater of Bangladesh: Contamination in the food chain. In: Arsenic contamination: Bangladesh perspective. Ahmed MF (ed). Dhaka, ITNBangladesh, 2003, pp 203-26.

Holtan H, Kamp-Nielsen L, Stuanes AO. Phosphorus in soil, water and sediment: An overview. Hydrobiol 2004; 170: 1934 .

Khan AW, Ahmed SA. Arsenic in drinking water, health effects and management: A training manual. Dhaka, Department of Occupational and Environmental Health, National Institute of Preventive and Social Medicine (NIPSOM), 1997.

Tu C, Ma LQ. Effects of arsenate and phosphate on their accumulation by an arsenic-hyperaccumulator pteris vittata L. Plants Soil 2003; 249: 373-82.

Meharg AA, Rahman MM Arsenic contamination of Bangladesh paddy field soils: Implications for rice contribution to arsenic consumption. Environ Sci Technol. 2003; 37: 229-34.

Mitra AK, Das HK, Sengupta PK, Hossain A, Islam F, Rabbani $\mathrm{GH}$. Arsenic concentrations in rice, vegetables and fish in Bangladesh: A preliminary study. Environ Int. 2004; 30: 38387.

Malimai-Raja S, Bolan NS, Adriano DC, Robinson B. Arsenic contamination and its risk management in complex environment settings. Adv Agron. 2005; 86: 1-82. 
Meharg AA, Hartley-Whitaker J. Arsenite uptake and metabolism in arsenic resistant and non-resistant plant species. New Phytol. 2002; 154: 29-43.

Smith E, Naidu R, Alstron AM. Chemistry of inorganic arsenic in soil effect of phosphous, sodium and calcium on arsenic absorption. J Environ Quali. 2002; 3: 557-63.
Tam KH, Charbonneau SM, Bryee F, Lacroix G. Separation of arsenic metabolites in dog plasma and urine following intravenous injection of ${ }^{74} \mathrm{As}$. Anal Biochem. 1978; 86: 505-11.

WHO. Arsenic and arsenic compounds. Environmental Health Criteria 22. $2^{\text {nd }}$ ed, Geneva, World Health Organization, 2001. 